\title{
Effect of Different Plant Spacing on Growth and Yield of luffa El Gendy, S. A. A.
}

Department of vegetable breeding Research, Horticultural Research Institute, Agriculture Research Centre, Egypt

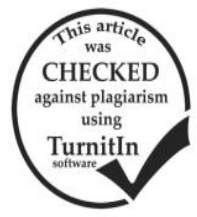

\section{ABSTRACT}

Two filed experiments were conducted at Moutobes district, Kafrelsheikh, Egypt during 2014 and 2015 seasons. The study amid to find out the performance of loofah plants under three plant spacing's 4X4 m, 6x6 and 6x8m. The observed results could be concluded as following: different plant spacing had a significant effect on studied characteristics of loofah plants in both seasons: Narrow plant spacing of $4 \times 4 \mathrm{~m}$ gave the maximum number of plants/fed, number of cobs/ plant, number of total cutting and average of yield kg harvests, fruits and yield / Fadden. Meanwhile, the lowest values of aforementioned traits were noticed by wider plant spacing of $6 \times 8 \mathrm{~m}$. Furthermore, plant spacing $6 \times 8 \mathrm{~m}$ produced longest ear diameter, ear length, plant height fruits good marketable $\%$ and number of seeds / fruit. On the other hand, plant spacing of $4 \times 4$ produced the lowest ones of plant spacing 6x6 was moderately and came in the second rank in all studied characters in both seasons.

\section{INTRODUCTION}

Sponge gourd (Luffa cylindrical) is belongs to Cucurbitaceae family, Luffa genus. It is used in two a vegetable either prepared like squash or eaten raw like cucumber (Sastri, 1962). Luffa cylindrica (L.) syn. Luffa aegyptiaca Mill., $(2 \mathrm{n}=26)$ commonly called sponge gourd, vegetable sponge, bath sponge or dish cloth gourd, is a member of Cucurbitaceae family (Sujatha et al., 2013). The immature fruits which that may have morphological differences based on the cultivar had high content of vitamin $\mathrm{C}$ and iron and they commonly used in soups mature fruits are bitter and inedible, but are reported to be used for medicinal purposes. The leaves are also edible. The seeds are a good source of iron, magnesium, and phosphorous and contain high amounts of essential amino acids such as lysine. However, seeds of some varieties are bitter tastily of seed attributed of seed due to high levels of steroids like Cucurbitac in B. The pure seed oil is tasteless and contains 68 percent of glycerides of oleic and linoleic acids, thus providing a good substitute for other vegetable oils such as from olive, safflower, and rape seed (Lung, 1993). Sponge gourd is known as important medicine plant, especially in China. Saponins from the leaves and fruits of luffas had apparent effect on anoxia and fatigue and immunological activity ( $\mathrm{Du}$ and Cui, 2007). A balanced fertilizer can be incorporated into the growing bed as a base fertilizer source before transplanting the seedlings. During the period of active vegetative growth, a fertilizer rich in nitrogen should be applied. Once flowers appear, the fertilizer with a higher phosphate ratio is then fed to the plants to support flower and fruit production (Wong, 2007). Plant spacing were found to range between $1.8-5.0 \mathrm{~m}$ for the interrows and 1.0- $4.0 \mathrm{~m}$ for the intra rows (Benzioni and Mendlinger (1988). A study conducted on L.aegyptica(Ko et al., 1978) demonstrated that a spacing of $1.5 \times 0.9 \mathrm{~m}$ can give optimum yields of about 9600 gourds/ha. Similarly, Kvaratskheliya, (1985), reported that a plant spacing of $2 \times 1 \mathrm{~m}$ gave a commercial yield of $292.7 \mathrm{~kg} / \mathrm{ha}$ per year as an average of 5 years. Davis (1994) studied the effects of planting date, planting method, in-row spacing $(30.5,61$, and 91 $\mathrm{cm}$ ) in luffa sponge gourd (Luffa aegyptiacaMill) to develop luffa for a cool, temperate climate. Highest marketable yields were obtained when plants were spaced $30.5 \mathrm{~cm}$ apart in the row and the first four lateral shoots were removed. Plants spaced $91 \mathrm{~cm}$ apart produced gourds with the largest diameter, whereas plants with $30.5-\mathrm{cm}$ in-row spacing produced the highest yields of gourds with bath sponge diameters $(5.1-7.6 \mathrm{~cm})$. Plants spaced $91 \mathrm{~cm}$ apart and topped at node six obtained high fiber density, strong fibers, and excellent visual appeal, but low yields. Yields were competitive with yields obtained in warmer climates. Each accession in each replication was represented by six plants in a plot size of $6 \mathrm{~m} 2$. The spacing was 100 $\mathrm{cm}$ between plants and $100 \mathrm{~cm}$ between rows (Phan et al., 2015). The present study was performed to find out the optimum plant spacing for Egyptian luffa.

\section{MATERIALS AND METHODS}

The current experiments were conducted at Moutobes district, Kafrelsheikh, Egypt during the two successive seasons of 2014 and 2015. Commercial seed lots in the terms of original population were cultivated. Seedling of loofahs plants were transplanted at 35 days seedling age in both seasons. Cultivation on May, 15 was done with three plant spacing of, $4 X 4 \mathrm{~m}, 4 \mathrm{X} 6 \mathrm{~m}$ and $4 \times 8 \mathrm{~m}$. The experimental fields were performed in randomized complete block design with four replications.

Plot area was $288 \mathrm{~m}^{2}(12 \mathrm{X} 24 \mathrm{~m})$ and each plot had three rows. The basal fertilizing consisted of 10 farmyard manure t/ha, $120 \mathrm{~kg}$ super phosphate per ha and $30 \mathrm{~kg}$ potassium per ha. Nitrogen in the rate of $250 \mathrm{~kg} \mathrm{~N} / \mathrm{ha}$ in the form of urea applied in to equal doses at basal application +60 days after transplanting.

A week before transplanting the field was liberally watered until weeds germinated. The plots were then sprayed with a herbicide, 2-4 D, at manufacturers recommended rates. The data were collected from five randomly selected plants per replication. Data were taken for the number of plants /fed, ear diameter, number of cobs / plant, Plant height (m) Number of total cutting, number of fruits / cutting, number of total fruits, Fruits good marketable \%, Number of seeds / fruit, Average of yield kg harvests fruits and Yield / Fadden. The obtained data were statistically analyzed according to snedecor and Cochran (1967). 


\section{RESULTS AND DISCUSSION}

Data in Table 1 indicated that different plant spacing had a significant effect number of plants and ear diameter of loofahs plants in both seasons. The maximum number of plants was obtained by narrow plant spacing $(4 \times 4)$ in both seasons. The biggest ear diameter was noticed by plant spacing of $6 \times 8 \mathrm{~m}$ in the two seasons. Meanwhile, the plant spacing $6 \times 6$ intermediated the other two plant spacing regarding the above-mentioned traits. The minimum value of the above mentioned traits were obtained by plant spacing $6 \times 8 \mathrm{~m}$ and $4 \mathrm{X} 4 \mathrm{~m}$ for ear diameter and number of plant spacing, respectively in both seasons. Bigger ear diameter under wider spacing is mainly attributed to less competition ensuring high growth rate and cell elongation. Similar findings were obtained by Benzioni and Mendlinger (1988).

Table 1. Effect of different plant spacing on number of plants/fed and ear diameter of loofahs plants in 2014 and 2015 seasons

\begin{tabular}{lcccc}
\hline Characters & \multicolumn{2}{c}{ Number of plants fed } & \multicolumn{2}{c}{ Ear diameter(cm) } \\
\cline { 2 - 5 } treatments & $\mathbf{2 0 1 4}$ & $\mathbf{2 0 1 5}$ & $\mathbf{2 0 1 4}$ & $\mathbf{2 0 1 5}$ \\
\hline 4X4 m & 252.00 & 255.00 & 33.25 & 34.25 \\
6 X6 m & 123.00 & 126.00 & 53.00 & 55.25 \\
6 X8 m & 85.00 & 86.00 & 70.00 & 63.75 \\
\hline LSD at 0.05 & 4.89 & 3.90 & 8.40 & 6.65 \\
\hline
\end{tabular}

Table 2. Effect of different plant spacing on ear length (cm)and number of cobs / plant of loofahs plants in 2014 and 2015 seasons

\begin{tabular}{lcccc}
\hline characters & \multicolumn{2}{c}{ Ear length (cm) } & \multicolumn{2}{c}{ Number of cobs /plant } \\
\cline { 2 - 5 } treatments & $\mathbf{2 0 1 4}$ & $\mathbf{2 0 1 5}$ & $\mathbf{2 0 1 4}$ & $\mathbf{2 0 1 5}$ \\
\hline 4X4 m & 51.00 & 55.00 & 18.25 & 18.25 \\
6X6 m & 75.00 & 73.75 & 10.25 & 11.50 \\
6X8 m & 106.00 & 100.00 & 11.75 & 12.50 \\
\hline LSD at 0.05 & 17.47 & 11.35 & 2.47 & 1.90 \\
\hline
\end{tabular}

Ear length and number of cobes of loofahs plants were markedly affected by plant spacing in 2014 and 2015 seasons (Table2). Plant spacing of $6 \times 8 \mathrm{~m}$ produced the tallest ear in the two seasons. On the other side, the shortest one was noticed by plant spacing $4 \times 4 \mathrm{~m}$ in the two second. On the contrary, the highest value of number of cobs was produced by plant spacing $4 \times 4$ meanwhile, the lowest value was produced by plant spacing $4 \times 4$ min both seasons. plant spacing 6x6 came in the second ranking for both ear length and number of cobes. Similar finding was previously discussed by $\mathrm{Du}$ and Cui (2007)

Table 3. Effect of different plant spacing on plant height ( $m$ ) and number of total cutting of loofahs plants in 2014 and 2015 seasons

\begin{tabular}{lcccc}
\hline $\begin{array}{l}\text { Characters } \\
\text { treatments }\end{array}$ & \multicolumn{2}{c}{ (Plant height (m) } & \multicolumn{2}{c}{ Number of total cuts } \\
\cline { 2 - 5 } & $\mathbf{2 0 1 4}$ & $\mathbf{2 0 1 5}$ & $\mathbf{2 0 1 4}$ & $\mathbf{2 0 1 5}$ \\
\hline $4 \mathrm{X} 4 \mathrm{~m}$ & 8.34 & 8.37 & 11.20 & 10.25 \\
$6 \mathrm{X} 6 \mathrm{~m}$ & 12.00 & 11.25 & 9.45 & 10.00 \\
$6 \mathrm{X} 8 \mathrm{~m}$ & 15.40 & 16.00 & 10.50 & 10.00 \\
\hline LSD at 0.05 & 2.08 & 1.59 & 1.80 & $\mathrm{NS}$ \\
\hline
\end{tabular}

As evident in Table 3 plant height and number of total cutting of loofahs plants were significantly influenced by plant spacing in the two seasons. The tallest plant was produced by plant spacing of $6 \times 8 \mathrm{~m}$. The shortest plant was obtained by plant spacing $4 \times 4$. With respect to number of total cutting of loofahs plants the highest value was produced by plant spacing $4 \times 4$ while the lowest value noticed by maximum plant spacing $(6 \times 6 \mathrm{~m})$ in the first season only. The plant spacing of $6 \times 6$ was moderately and came in the second rank for with respect to plant height of loofahs plants in both seasons. Narrow spacing developed more computation a many plant restricted its growth resulted in sort plant Similar results were reported by (Davis 1994)

Table 4. Effect of different plant spacing on number of fruits / cutting and number of total fruits of loofahs plants in 2014 and 2015 seasons

\begin{tabular}{lcccc}
\hline $\begin{array}{l}\text { Characters } \\
\text { treatments }\end{array}$ & \multicolumn{3}{c}{ Number of fruits cut Number of total fruits } \\
\cline { 2 - 5 } & $\mathbf{2 0 1 4}$ & $\mathbf{2 0 1 5}$ & $\mathbf{2 0 1 4}$ & $\mathbf{2 0 1 5}$ \\
\hline 4X4 m & 389.50 & 405.00 & 4525.00 & 4125.00 \\
6X6 m & 343.75 & 340.00 & 3747.50 & 2925.00 \\
6X8 m & 275.00 & 281.25 & 3477.00 & 3796.00 \\
\hline LSD at 0.05 & 20.4 & 31.12 & 885.51 & 265.29 \\
\hline
\end{tabular}

Number of fruits / cutting and number of total fruits of loofahs plants were significantly affected by plant spacing in both seasons. However, plant spacing $4 \times 4$ gave the maximum values of abovementioned traits, followed by the plant spacing $6 \times 6$. Meanwhile, the lowest values of number of fruits / cutting and number of total fruits of loofahs plants were produced by plant spacing $6 \times 8 \mathrm{~m}$ in both seasons. These results stand in well agreement with those of Du and Cui (2007).

Table 5. Effect of different plant spacing on Fruits good marketable \%and number of seeds / fruit of loofahs plants in 2014 and 2015 seasons

\begin{tabular}{lcccc}
\hline \multirow{2}{*}{$\begin{array}{l}\text { Characters } \\
\text { Treatments }\end{array}$} & \multicolumn{2}{c}{$\begin{array}{c}\text { Fruits good marketable } \\
\text { \% }\end{array}$} & \multicolumn{2}{c}{$\begin{array}{c}\text { Number of seeds } \\
\text { fruit }\end{array}$} \\
\cline { 2 - 5 } & $\mathbf{2 0 1 4}$ & $\mathbf{2 0 1 5}$ & $\mathbf{2 0 1 4}$ & $\mathbf{2 0 1 5}$ \\
\hline 4 X4 m & 40.25 & 48.75 & 315.00 & 288.75 \\
6 X6 m & 62.50 & 63.00 & 425.00 & 401.25 \\
6 X8 m & 74.50 & 72.50 & 692.50 & 520.00 \\
\hline LSD at 0.05 & 14.50 & 9.74 & 63.76 & 74.69 \\
\hline
\end{tabular}

Regarding, data in Table5 show that plant spacing had a positive impact on fruits good marketable $\%$ and number of seeds / fruit of loofahs plants in both seasons. The highest value of fruits good marketable $\%$ and number of seeds / fruit were produced by $6 \times 8 \mathrm{~m}$ in both seasons. Plant spacing $6 \times 6$ came in the second rank. On contrary, the lowest values were observed by plant spacing $4 \times 4 \mathrm{~m}$ in the two seasons. Wider spacing induced low competition reflect on the fruit quality attributed to high fruits good marketable \% and higher number of seed/fruit. Similar data was obtained by Davis (1994) 
Table 6 . Effect of different plant spacing on average of yield $\mathrm{kg}$ harvests fruits and yield / fadden of loofahs plants in 2014 and 2015 seasons

\begin{tabular}{lcccc}
\hline Characters & \multicolumn{2}{c}{$\begin{array}{c}\text { Average of yield kg } \\
\text { harvests fruits }\end{array}$} & \multicolumn{2}{c}{$\begin{array}{c}\text { YYield kg } \\
\text { Fadden }\end{array}$} \\
\cline { 2 - 5 } Treatments & $\mathbf{2 0 1 4}$ & $\mathbf{2 0 1 5}$ & $\mathbf{2 0 1 4}$ & $\mathbf{2 0 1 5}$ \\
\hline 4X4 m & 398.8 & 397.4 & 3989.2 & 3975 \\
6 X6 m & 385.7 & 383.2 & 3850.4 & 3860 \\
6 X8 m & 373.3 & 371.3 & 3740.3 & 3770.3 \\
\hline LSD at 0.05 & 13.0 & 14.0 & 86.0 & 78.0 \\
\hline
\end{tabular}

Average of yield $\mathrm{kg}$ harvests fruits and yield / Fadden of loofahs plants were significantly affected by plant spacing in both seasons (Table6). Plant spacing $4 \times 4$ gave the maximum values of average of yield $\mathrm{kg}$ harvests fruits and yield / Fadden, followed by the plant spacing 6x6. Meanwhile, the lowest values average of yield $\mathrm{kg}$ harvests fruits and yield / Fadden were produced by plant spacing $6 \times 8 \mathrm{~m}$ in both seasons. Narrow spacing was apparently produced the higher plants number per unit area that attributed to high yield per feddan. The same time the quality of luffas ear was low unde narrow planting space comparing to wider space. The current results stand in well agreement with those of Kvaratskheliya (1985) and Phan et al. (2015).

\section{REFERENCES}

Benzioni, A. and S. Mendlinger(1988). Development and optimization of agrotechniques for tropical vegetable production. Progress report BGUNARI-6-88. pp1-5.

Davis, J.M.(1994).Luffa sponge gourd production practices for pemperate plimates. Hort Sci..,29(4):263-266.

Du, Q., and H. Cui(2007). "A New Flavones Glycoside from the Fruits of Luffa cynlindrica." Fitoterapia78:609-10. (c.f. computer search)
Ko, B.R.; K.B. Lee; J.S. La; S.P. Nho and D.K. Lee(1978).Studies on the effect of planting density and manurial rate on the growth of Luffa cylindrica. Research Reports Of the growth of Rural Development, Horticulture and Agricultural Engineering. 20, 47-50.

Kvaratskheliya, D.A.(1985). Determination of optimal spacing in Luftacultivation in the Kolkhida lowland. SubtropicheskieKul'tury 1: 49-51. .(c.f. computer search)

Lung, A. R.(1993).Fruit yield and quality of ridge gourd (Luffa acutangula (L) Roxb) as influenced by plant density and varietal differences as ascertained by isozyme analysis. M.Sc. Thesis, Faculty of Agriculture, University of Nairobi, Kenya.

Phan, T.T.; H.T.H. Truong; S.C.H. Nguyen; T.T.T. Nguyen and T.V. Tran(2015). Evaluation of Promising Sponge Gourd (Luffa cylindrical) Accessions in Summer-Autumn Season 2014 in ThuaThien Hue. Journal of Agricultural Science and Technology A and B \& Hue University J. of Sci. 5 (1) 508-514.

Sastri, B.N. (1962). Wealth of India: A Dictionary of Indian Raw Materials and Industrial Products. Vol. 6.New Delhi: CSIR.

Snedecor,C,W. and J.W.Cochran (1967). Statistical methods, 6th ED, Iowa State Univ., Press. Ames, Iowa, USA.

Sujatha, D.; R. Chithakari; L. Raghuvardhan; B. Prasad; R.G. Khan; A. Sadanandam and T. C. Reuben(2013).In vitro plantlet regeneration and genetic transformation of sponge gourd (Luffa cylindricaL.).African J. of Plant Sci. 7(6): 244252.

Wong, W.(2007). The luffa - for food, sponges \& more. Green Culture Singapore Feature Article for August 2007 Published online 1 September 2007.

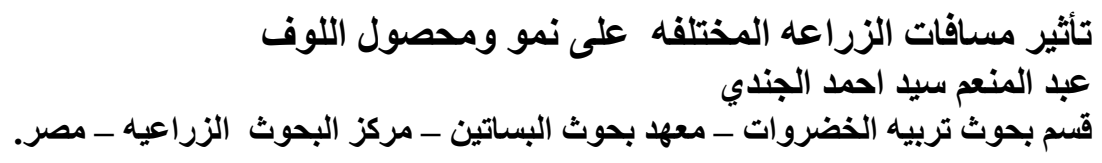

أقيمت تجربتان حقليتان بمركز مطوبس- محافظه كفر الشيخ خـلال موسمى الزر اعـه 2014و 2015 وذللك لمعرفه تأثير مسافات

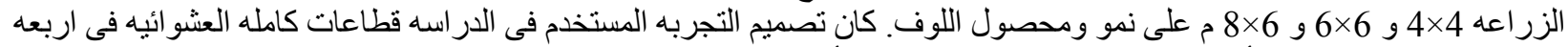

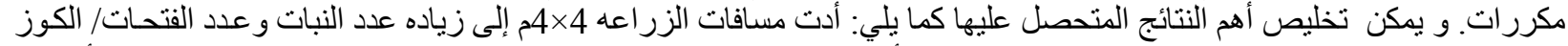

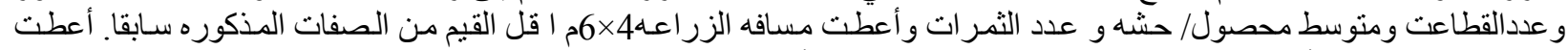

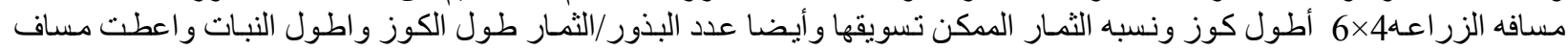

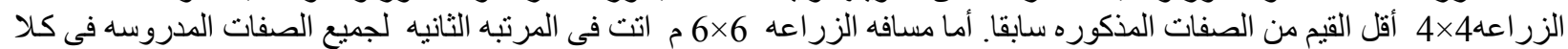

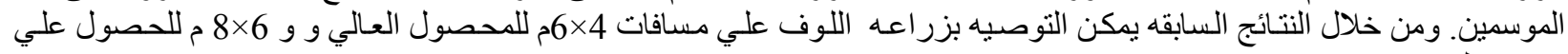

